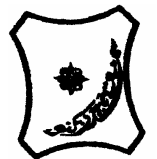

Bayero Journal of Pure and Applied Sciences, 4(2): $53-55$

Received: June, 2011

Accepted: October, 2011

ISSN $2006-6996$

\title{
PREVALENCE OF URINARY SCHISTOSOMIASIS AMONG SCHOOL AGED CHILDREN IN WUSHISHI LOCAL GOVERNMENT AREA OF NIGER STATE, NIGERIA
}

\author{
*Abdullahi, M. and Saidu, T.B. \\ Department of Basic and Applied Sciences Niger State Polytechnic, Zungeru, Niger State, Nigeria \\ *Correspondence author: Iddabdul@yahoo.com
}

\begin{abstract}
An investigation was conducted to determine the prevalence of urinary Schistosomiasis in two localities namely, Wushishi and Zungeru of Wushishi local government of Niger State. Urine samples were collected from 100 school children of each of the two localities and investigated for eggs of Shistosoma haematobium using standard filtration techniques. The water contact activities of the inhabitants whose samples were collected were also obtained, using questionnaire method. Result obtained showed that 80 (40.0\%) inhabitants were infected with a mean egg count. The infection rate was found to be higher among males $(47.5 \%)$ than the females $(28.75 \%)$ but the mean eggs count tend to be higher among the females $(7.5 \mathrm{eggs} / 10 \mathrm{ml}$ of urine) than males $(5.8 \mathrm{eggs} / \mathrm{ml}$ of urine). The results also showed that children aged 10 - 15 yrs old had the highest infection rate of $48.75 \%$ with 16.0 eggs $/ 10 \mathrm{ml}$ of urine.
\end{abstract}

Key words: prevalence, urinary schistosomiasis

\section{INTRODUCTION}

The Schistosomiasis or blood fluke infections are major parasitic infections of the blood stream caused by trematodes of the genus Schistosoma. It is the second parasitic infection to malaria interms of public health importance (Cheesbrought, 2003). Despite all effort by different health organizations to control the life cycle of the parasite it remains a global public health problem (WHO, 1998). The disease is endemic in 75 countries where over 600 million people are at risk of infection, with over 200 million infected, and about 100,000 at health risk (WHO, 1998). Schistosomiasis is now considered the most serious rural health problem in Nigeria. Approximately ten (10) million people, between $15-30 \%$ of the population are said to be infected with either or both $S$. mansoni and $S$. haematobium (Joklik et al.; 1988). There are three species that occur commonly in humans: Schistosoma japonicum, Schistosoma mansoni and Schistosoma heamatobium ( Joklik et al.; 1988). Schistosomiasis is one of the most important water borne diseases of socio-economic and public health importance (Woolhouse et al.; 1999). Of the three main species affecting man, two, namely, Schistosoma mansoni (causing intestinal schistosomiasis) and Schistosoma haematobium (causing the urinary form) are endemic in Nigeria especially irrigation project areas (Istifanus et al.; 2000). Schistosoma infections are mostly acquired through body contact with the polluted water containing the infective stage (cerceria) of the parasite (Abubakar et al.; 2006). The objectives are to determine the prevalence of urinary schistosomiasis among school aged children in Wushishi Local Government Area of Niger State and to ascertain the level of infections among the pupils.

\section{MATERIALS AND METHODS}

\section{Study area}

Zungeru and Wushishi are rural towns situated about $63 \mathrm{~km}$ and $77 \mathrm{~km}$ respectively from Minna, the capital of Niger State, Nigeria. Subsistence farming, fishing and trading are the major occupations of the people of these area. The nature of water bodies found in the area is running water and surface water. The inhabitants mostly depend on this water source for domestic use and activities (bathing, washing of clothes, etc).

\section{Collection and Analysis of Urine Sample}

Urine samples were randomly collected mainly from school children of Wushishi central primary school and Zungeru central primary school. Within the period of July - August, 2010, between the hours of 9:00am $12: 00 \mathrm{pm}$.; as egg output from infected persons reach their peak value around that time of the day (Agbolade and Odaibo, 1996). Samples were collected in specimen bottles and taken to the laboratory for analysis. Information on sex, age and water contact activities were recorded against each specimen collected.

Urine samples were analysed and identified using the standard filtration technique as described by Adeoye and Ipeayedo (1994). A $5.5 \mathrm{~cm}$ Whartman filter paper was inserted in the filtration unit. The urine sample was shaken and $10 \mathrm{ml}$ was withdrawn using $5 \mathrm{ml}$ syringe (twice) and injected into the filtration unit. After filtration, the filter paper was removed carefully using forceps and a drop of iodine was added. The stained filter paper was allowed to dry for about 5 minutes after which it was placed on a clean slide and observed systematically under microscope at x10 magnification. Eggs were counted and result was recorded and expressed as number of eggs per $10 \mathrm{ml}$ of urine. 


\section{RESULTS}

The result of this research (Table 1 ) shows that out of 200 inhabitants examined, $80(40.0 \%)$ were infected with Schistosoma haematobium, with a mean intensity of $28 \mathrm{eggs} / 10 \mathrm{ml}$ of urine. Both prevalence and intensity varied from one community to another. The results showed that Zungeru has higher prevalence $(54 \%)$ followed by Wushishi $(26 \%)$. The intensity of S. haematobium infection varied from $16.5 \mathrm{egg} / 10 \mathrm{ml}$ of urine to $11.5 \mathrm{eggs} / 10 \mathrm{ml}$ of urine among the villages. The higher mean intensity of infection was recorded in Zungeru (16.5 eggs/10ml of urine) followed by Wushishi children (11.5eggs/10ml of urine).

The result further showed (Table 2) that prevalence was higher among the males with $47.50 \%$ than with females $28.75 \%$. The intensity of infection was observed to be higher among the females with 7.5 eggs/10ml compare to males with 5.8 eggs/10ml of urine. However, statistical analysis shows that no significant difference $(P>0.5)$ existing between the sexes.

The prevalence among the age group showed that group aged $10-15$ years had the highest prevalence of $48.75 \%$ followed by $01-09$ years with $31.25 \%$ and 16 - 20 years with $40 \%$ (Table 3). The highest intensity of infection was observed among age group of $10-15$ years (16.0 eggs $/ 10 \mathrm{ml})$, followed by $01-09$ years $(7.0$ eggs/10ml) and 16 - 20 years of age with 5.0 eggs/10ml of urine (Table 3 ). Analysis of water contact activities by the children of the two villages studied showed that those of Zungeru had more water contact activities compare to inhabitants of Wushishi (Table 4).

Table 1: Prevalence of Urinary Schistosomiasis Among School Aged Children of Zungeru and Wushishi Central Primary Schools

\begin{tabular}{lcccc}
\hline \multicolumn{1}{c}{ STUDY AREA } & $\begin{array}{c}\text { NO } \\
\text { EXAMINED }\end{array}$ & $\begin{array}{c}\text { NO } \\
\text { POSITIVE }\end{array}$ & $\begin{array}{c}\text { PREVALENCE } \\
(\mathbf{\%})\end{array}$ & $\begin{array}{c}\text { INTENCITY } \\
\text { (mean eggs/10mI) }\end{array}$ \\
\hline Zungeru & 100 & 54 & 54 & 16.5 \\
Wushishi & 100 & 26 & 26 & 11.5 \\
TOTAL & $\mathbf{2 0 0}$ & $\mathbf{8 0}$ & $\mathbf{4 0 . 0}$ & $\mathbf{2 8}$ \\
\hline
\end{tabular}

Table 2: Sex distribution of the Schistosomiasis Among School Aged Children of Zungeru and Wushishi Central Primary Schools

\begin{tabular}{lcccc}
\hline \multicolumn{1}{c}{ SEX } & $\begin{array}{c}\text { NO } \\
\text { EXAMINED }\end{array}$ & $\begin{array}{c}\text { NO } \\
\text { POSITIVE }\end{array}$ & $\begin{array}{c}\text { PREVALENCE } \\
(\boldsymbol{\%})\end{array}$ & $\begin{array}{c}\text { INTENCITY } \\
\text { (mean eggs/10ml) }\end{array}$ \\
\hline Male & 120 & 57 & 47.50 & 5.8 \\
Female & 80 & 23 & 28.75 & 7.5 \\
TOTAL & $\mathbf{2 0 0}$ & $\mathbf{8 0}$ & $\mathbf{4 0 . 0 0}$ & $\mathbf{1 3 . 3}$ \\
\hline
\end{tabular}

Table 3: Age- group Distribution of the Pupils Analysed for Schistosomiasis Among School Aged children of Zungeru and Wushishi Central Primary Schools.

\begin{tabular}{lcccc}
\hline $\begin{array}{c}\text { AGE (YRS.) } \\
\text { GROUP }\end{array}$ & $\begin{array}{c}\text { NO } \\
\text { EXAMINED }\end{array}$ & $\begin{array}{c}\text { NO } \\
\text { POSITIVE }\end{array}$ & $\begin{array}{c}\text { PREVALENCE } \\
(\mathbf{\%})\end{array}$ & $\begin{array}{c}\text { INTENCITY } \\
\text { (mean eggs/10ml) }\end{array}$ \\
\hline $01-09$ & 80 & 25 & 31.25 & 7.0 \\
$10-15$ & 80 & 39 & 48.75 & 16.0 \\
$16-20$ & 40 & 16 & 40.00 & 5.0 \\
TOTAL & $\mathbf{2 0 0}$ & $\mathbf{8 0}$ & $\mathbf{4 0 . 0 0}$ & $\mathbf{2 8}$ \\
\hline
\end{tabular}

Table 4: Water Contact Activities of the Pupils (\% of pupils per activities)

\begin{tabular}{lcc}
\hline ACTIVITIES & WUSHISHI & ZUNGERU \\
\hline FISHING & 70 & 66.0 \\
WASHING CLOTHES & 45.0 & 85.0 \\
BATHING \& SWIMMING & 50.0 & 75.0 \\
FETCHING WATER & 40.0 & 85.0 \\
\hline
\end{tabular}

\section{DISCUSSION}

The high prevalence (40.0\%) observed in this study suggests a high risk of infection which may likely result in disease complications of urinary Schistosomiasis in Zungeru and Wushishi. The occurrence of Schistosoma in the study area may be as a result of water pollution by $S$. haemtobium eggs, water contact activities, presence of fresh water snail (intermediate host) and frequent water contact activities which corroborate the findings of Abubakar et al. (2006), in Northern part of Nigeria.

The infection rate was higher in Zungeru, compare to the infection rate at Wushishi. However, the stream or river water at Zungeru is the only major source of their (inhabitant) drinking water as well as domestic activities. Therefore, the high rate of infection may be as a result of intense water contact by the children and dependence on the river water. Engweunyenga et al.(1994), Abubakar and Adamu (2001) made similar observation in prevalence of Schistosomiasis in Bauchi and Dundaye district in Sokoto respectively.

The higher prevalence among males (47.5\%) than the females $(28.75 \%)$ could be due to the greater water contact activities by male compared to the females in the Zungeru and Wushishi. However, it was observed that females were less prone to long period of swimming and therefore had less exposure to water activities (swimming) compare to males. 
Olusanya and Odiomu (1984) as well as Edungbola et al. (1988) stated that females mature earlier and are therefore restricted socially compare to males to swim naked in the stream.

The study shows that children between the age of $10-15$ years had the highest prevalence followed by the children aged between 01- 09 years. Thus, the rise in prevalence with age could be attributed to exposure factor. Consequently, at early age, water contact activities such as swimming, washing and bathing inside the water (river) body are less and these activities could increase with age and maturity ( Adeoye and Ipeayedo, 1994; Engwunyega et al., 1994).

Reduction in egg intensity with age (5.0 eggs $/ 10 \mathrm{ml}$ ) in children could be related to the fact that Schistosomiasis increases with age of infected subjects and eggs become trapped and calcified in the

\section{REFERENCES}

Abubakar .U, Adamu .T and Ishaku N.T. (2006): Prevalence of Urinary Schistosomiasis Among Inhabitants of Four Local government of Sokoto State. Nigeria journal of Basic and Applied Sciences Vol. 14 (1\&2). P 23

Abubakar, U. and Adamu. (2001). Prevalence of Schistosomiasis in two communities of Dundaye District of Sokoto State Nigeria Journal of Basic and Applied Sciences. 10: 52- 53.

Adeoye G.O, and Ipeayeda M. (1994). Schistosoma haematobium infection among school children in Owena Army Barracks, Akure, Nigeria, The journal of Parasitology 15: 43 48.

Agbolade O.M and A.B Odiabo (1996): Schistosoma infection among pupils and snail intermediate host in Ago Iwaye, Ogun State. Journal of Applied Science. 16: 45-60.

Cheesbrought M. (1987): Medical Laboratory Mannual for tropical countries. Vol.1 $2^{\text {nd }}$ edition ELBS. Butterworth, theenemann (Great Britain). p22 - 101.

Edungbola, L.D, Asaolu, S.O, Omonis, K.K and Aiyedun, B.A (1988): Schistosoma bladder and thus, reducing egg excretion (Abubakar et al., 2006).

\section{CONCLUSION}

The infection with Schistosoma, have been established in these study area. However, there is no control programme on the disease in Wushishi Local Government for now. If the situation is left unchecked without proper control, it may affect the standard of education in the village, as well as the productivity in the village may also be affected.

\section{RECOMMENDATIONS}

1. Mass education of the childrens as well as inhabitants, to create awareness on the mode of infection with the organism.

2. Utmost government intervention to the community on the control and treatment of the infected pupils.

haematobium infection among school children in the Babana district Kwara State Nigeria. Africa Journ. Med. And Medic. Sciences, $17:$ 186-190.

Egweunyenga, O.A, Nmorsi, P. and Omokauje, O.O (1994): Schistosomiasis in Bauchi State Nigeria, Nig. Journ. Of Parasitology. 12: 3339.

Istifanius, W.A, Mohammed K.M and Mohammed D.M (2000) Prevalence and Intensity of Shcistosoma infection among the Primary School Children in Bauchi State. Nigeria Journal of Parasitology. Vol. 9 11.pp. $55-59$

Joklik .k, Wolfgang, Willet .P, Hilda, Amos B.D and Wilfert M.C (1988) Zinsser Microbiology $19^{\text {th }}$ Edition Pp991 - 994.

Olusanya O.O and Odiomu F.A, (1984). Scistosomiasis in Volta Region of Ghana Ann. Trop. Med. and Parasitology. 51 (1) : $9-10$.

WHO (1998) Tropical Disease Research Progress 1997/98. WHO Geneva.

Woolhouse, M.E. Mutapi J, Ndh, F, Chandiwana P.D and Hagan P. (1999). Exposure, Infection and Immune Response to $S$. haematobium. Journal of Parasitology. 120 (1). Pp 20 - 34. 